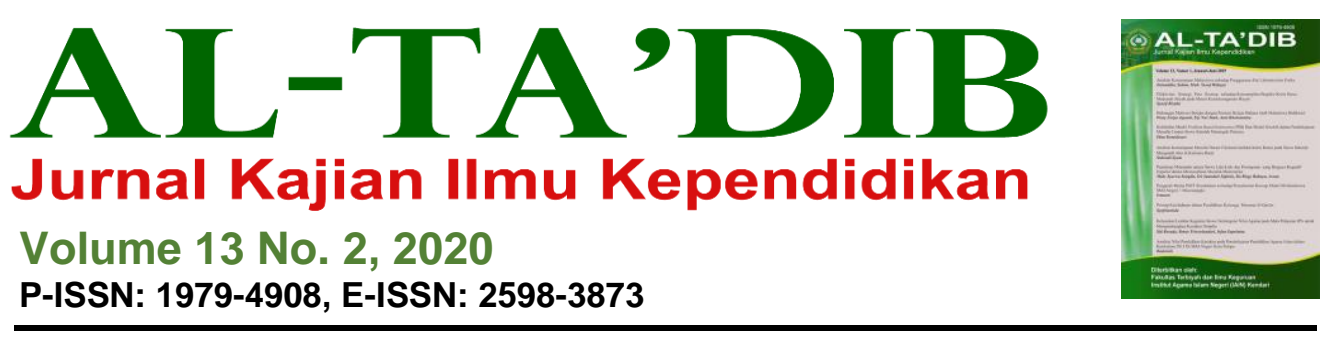

\title{
Implementasi Pemberdayaan Pengawas terhadap Efektivitas Supervisi Pengawas Pendidikan Agama Islam
}

\author{
Sufiani $^{1}$, Aris Try Andreas Putra ${ }^{2}$ \\ ${ }^{1}$ Institut Agama Islam Negeri Kendari, Indonesia.E-mail: Sufianifatik1969@gmail.com \\ ${ }^{2}$ Institut Agama Islam Negeri Kendari, Indonesia. E-mail: aristriandreasputraaritonda@gmail.com
}

\begin{tabular}{l} 
ARTICLE INFO \\
\hline Keywords: \\
Effectiveness; \\
empowerment; \\
implementation; Islamic \\
religion education; \\
supervision; supervisor \\
How to Cite: \\
Sufiani, \& Putra, A. T. A. \\
(2020). Implementasi \\
pemberdayaan pengawas \\
terhadap efektivitas \\
supervisi pengawas \\
pendidikan agama Islam. \\
Al-Ta'dib: Jurnal Kajian \\
Ilmu Kependidikan, 13(2), \\
113-127.
\end{tabular}

\begin{abstract}
This paper presents the finding of qualitative study aiming to describe the implementation of supervisor empowerment to the effectiveness of supervision of Islamic education supervisors at Southeast Sulawesi, Indonesia. The data were collected from observation, interviews, and documentation. The findings indicate that the supervisors of Islamic education have been well empowered through the implementation of trust, authority, encouragement, and responsibilities. They have been well empowered through trust, power, encouragement and implementation of responsibilities. They can perform their main duties, authority, and responsibilities effectively through assisting teacher, assisting and assessing teachers' administration, as well as assisting and assessing teachers' academic.
\end{abstract}


INFORMASI ARTIKEL

Kata Kunci:

Efektivitas; implementasi; pemberdayaan; pendidikan agama Islam; pengawas; supervisi

Cara Mensitasi:

Sufiani, \& Putra, A. T. A. (2020). Implementasi pemberdayaan pengawas terhadap efektivitas supervisi pengawas pendidikan agama Islam. Al-Ta'dib: Jurnal Kajian Ilmu Kependidikan, 13(2), 113-127.

\begin{abstract}
ABSTRAK
Artikel ini menyajikan hasil penelitian kualitatif yang fokus pada implementasi pemberdayaan pengawas terhadap efektivitas supervisi pengawas pendidikan agama Islam di Sulawesi Tenggara, Indonesia. Data dikumpulkan melalui observasi, wawancara langsung, dan pengumpulan dokumen yang relevan. Temuan penelitian menunjukkan bahwa pengawas pendidikan agama Islam telah diberdayakan dengan baik melalui pemberian kepercayaan, kekuasaan, dukungan, dan implementasi tanggung jawab. Mereka dapat menjalankan tugas utama, wewenang, dan tanggung jawab secara efektif melalui pembinaan guru dalam hubungan struktural, pembinaan dan penilaian administrasi guru serta pembinaan dan penilaian akademik guru.
\end{abstract}

\section{Pendahuluan}

Problematika dalam dunia pendidikan di Indonesia yang dirasakan saat ini cukup banyak, mulai dari persoalan kurikulum, kompetensi, profesionalisme dan lain-lain. Beragam keluhan dalam lingkungan pendidikan masih terjadi, baik yang dialami oleh tenaga pendidik maupun tenaga kependidikan di sekolah (Nasution, 2014). Selain itu, Indonesia masih berada di urutan bawah dalam peringkat pendidikan bila dibandingkan dengan negara-negara lain di dunia. Posisi Indonesia bahkan tertinggal dengan beberapa negara tetangga di Asia Tenggara seperti Malaysia, Brunei dan Thailand. Terkait kondisi pendidikan di Indonesia saat ini, Widodo (2015) melaporkan bahwa layanan dalam bidang pendidikan dan mutu pendidikan di Indonesia masih berada pada peringkat yang buruk dan perlu segera dibenahi agar tidak semakin terpuruk dan tidak berimbas pada sektor lainnya. Untuk menghadapi problematika tersebut, pemerintah Indonesia secara terus-menerus melaksanakan upaya peningkatan mutu pendidikan di berbagai jenis dan jenjang pendidikan. Salah satu program peningkatan mutu pendidikan yang dilakukan oleh pemerintah adalah peningkatan mutu tenaga kependidikan, termasuk pengawas pendidikan agama Islam karena mereka memiliki peran penting dalam upaya peningkatan mutu pendidikan di Indonesia (Amiruddin, 2018; Rahmah, 2018).

Program pengawas pendidikan agama Islam mencakup kegiatan yang akan dijalankan untuk memperbaiki kinerja guru dalam meningkatkan situasi pembelajaran yang menjadi tanggung jawabnya. Di dalam program supervisi tertuang berbagai usaha dan tindakan yang perlu dijalankan agar supaya 
pembelajaran menjadi lebih baik sehingga akselerasi belajar peserta didik semakin cepat dalam mengembangkan potensi dirinya (Bakar, 2011). Program supervisi pengawas pendidikan agama Islam dimaksudkan untuk memperbaiki dan meningkatkan proses dan hasil pembelajaran agar kegiatan pembinaan relevan dengan peningkatan kemampuan profesional guru. Program supervisi harus realistik dan dapat dilaksanakan sehingga benarbenar membantu meningkatkan kinerja guru (Rohman, 2018).

Slameto (2016) menegaskan bahwa program supervisi yang baik mencakup keseluruhan proses pembelajaran yang membangun lingkungan pembelajaran yang kondusif mencakup maksud dan tujuan, pengembangan kurikulum, metode mengajar, evaluasi, dan pengembangan pengalaman belajar peserta didik yang direncanakan baik dalam intra maupun extra kurikuler. Program supervisi menekankan pada proses pembinaan guru dengan memberi motivasi bagi pertumbuhan kemampuan profesionalnya dalam melaksanakan pembelajaran (Adu, Akinloye, \& Olaoye, 2014). Program ini menjadi bagian integral dalam upaya peningkatan mutu sekolah serta didukung semua pihak, termasuk pendanaan dan fasilitas. Supervisi bukan kegiatan tambahan tetapi sebagai kegiatan yang memerlukan perencanaan sistemik untuk mencapai tujuan secara efektif.

Untuk mencapai hasil kegiatan supervisi yang maksimal maka pengawas harus melakukan perencanaan dengan matang (Slameto, 2016). Pengawas menyusun rencana untuk memperkuat implementasi keempat kompetensi guru, yaitu kompetensi pedagogik, kompetensi kepribadian, kompetensi sosial dan kompetensi profesional. Selain itu, dalam pelaksanaan supervisi, pengawas dituntut terampil menggunakan instrumen, mampu mengembangkan instrumen, mampu menguasai materi yang akan disupervisi dan mampu melakukan tugasnya secara berkesinambungan. Setelah proses supervisi dilakukan, penilaian diperlukan di setiap pertemuan akhir. Tujuannya untuk menindaklanjuti apa saja yang dilihat pengawas sebagai pengamat dalam proses pembelajaran. Tahap ini menekankan pada identifikasi dan analisis persamaan dan perbedaan antara perilaku guru dan siswa yang direncanakan dengan perilaku aktual guru dan siswa di kelas. Pengawas bertugas menanamkan kepercayaan diri guru dan memberi umpan balik. Setelah itu dilanjutkan dengan analisis setiap aspek pengajaran yang menjadi perhatian supervisi tersebut.

Berdasarkan beberapa penjelasan tersebut di atas maka pengawas, termasuk pengawas pendidikan agama Islam memiliki tugas, fungsi dan tanggung jawab dan wewenang yang penting dalam pelaksanaan pengawasan guru pendidikan agama Islam di sekolah. Tugas, fungsi, tanggung jawab dan wewenang tersebut harus dilaksanakan dengan sebaik-baiknya dengan penuh rasa tanggung jawab dalam rangka tercapainya tujuan pendidikan di sekolah pada khususnya dan di Indonesia pada umumnya. Selain itu, pengawas 
pendidikan agama Islam sebagai pegawai negeri sipil yang diangkat dalam jabatan fungsional harus memiliki pengetahuan, keterampilan dan kepribadian yang baik untuk menunjang pelaksanaan tugasnya. Hendri (2020) menegaskan bahwa salah satu peranan pengawas pendidikan agama Islam adalah menciptakan suasasana yang bisa membuat guru merasa aman dan bebas dalam menjalankan tugasnya serta mengembangkan potensi dan kreatifitasnya dengan penuh profesionalisme tanggung jawab.

Ada beberapa kompetensi yang harus dimiliki oleh pengawas pendidikan agama Islam pada sekolah. Beberapa diantaranya adalah kompetensi kepribadian, kompetensi suervisi akademik dan kompetensi evaluasi pendidikan. Kompetensi kepribadian harus dimiliki oleh pengawas pendidikan agama Islam agar dalam melaksanakan tugasnya dapat dijadikan panutan. Kompetensi kepribadian yang dimiliki pengawas membawa pengaruh positif terhadap pelaksanaan tugasnya. Indikasi tersebut dapat ditandai apabila kompetensi kepribadian pengawas meningkat maka pelaksanaan supervisi pengawas akan membuahkan hasil yang optimal (Pristiwaluyo \& Hakim, 2018). Selain itu, ada juga kompetensi supervisi akademik yang harus dimiliki oleh pengawas pendidikan agama Islam agar dapat melaksanakan tugasnya sebagai supervisor pembelajaran (Oma, 2012). Hal penting yang harus pula dimiliki oleh pengawas adalah kompetensi evaluasi pendidikan agar dalam mengumpulkan, mengolah, dan menafsirkan informasi dapat dilakukan sesuai profesinya yang meliputi penilaian proses dan hasil belajar, program pendidikan dan kinerja guru (Alimin, Taena, \& Suardika, 2018). Ketiga kompetensi inilah yang wajib dimiliki oleh pengawas pendidikan agama Islam dalam menyelesaikan tugas dan kewajibannya dengan baik.

Pengawas pendidikan juga diharapkan memiliki beberapa kemampuan yang mampu menunjang kinerja dalam melakukan supervisi, misalnya kemampuan komunikasi yang mumpuni dan mampu mengekspresikan idenya dalam bentuk tulisan. Sebagai implementasi dari kompetensi tersebut maka pengawas pendidikan agama Islam harus menjalin mitra kerja dengan kepala sekolah, guru dan stakeholders lainnya. Pengawas juga harus bermitra dengan individu maupun kelompok yang berkaitan dengan peningkatan mutu pendidikan di sekolah. Selain itu, pengawas pendidikan agama Islam harus dapat menulis untuk menghasilkan karya ilmiah berdasarkan hasil penelitian dan survey evaluasi pada komponen pendidikan. Mereka harus pula menguasai substansi materi pembelajaran, model, strategi dan metode pembeajaran serta mampu mengikuti kemajuan perkembangan ilmu pengetahuan dan teknologi dewasa ini (Rahmah, 2018).

Terkait dengan studi yang pernah dilakukan dalam bidang pengawasan pendidikan Islam, Gusmadi (2014) menemukan bahwa pelaksanaan pengendalian manajemen pendidikan agama Islam terdiri atas 
pengawasan supervisi akademik dan supervisi manajerial. Temuan dari pelaksanaan supervisi ini menunjukkan bahwa dalam aspek perencanaan mereka telah menyusun rencana supervisi, tetapi perencanaan tersebut belum sepenuhnya dilaksanakan baik pada supervisi akademik maupun manajerial. Selain itu, pelaksanaan tugas-tugas supervisi menunjukkan belum adanya supervisor untuk melaksanakan pengawasan yang baik sesuai dengan tugas dan fungsi pembimbing akademik maupun manajerial. Selain itu, aspek regulasi evaluasi menunjukkan bahwa evaluasi tidak sepenuhnya berjalan.

Maranting (2020) menemukan bahwa bahwa supervisi atau pengawasan yang dilakukan oleh pengawas pendidikan agama Islam bertujuan untuk memberikan pelayanan atau pendampingan terhadap kualitas pengajaran guru di kelas yang pada akhirnya akan meningkatkan kualitas pembelajaran siswa. Beberapa usahanya adalah dengan mengadakan pertemuan antara pengawas dan madrasah, pertemuan kelompok kerja guru (KKG), kelompok kerja (Pokja), dan bimbingan guru mata pelajaran. Kendala yang dihadapi adalah kurangnya pengawas, masih ada guru yang tidak mau diawasi, ada guru yang merasa lebih senior dari pada pengawas, dan kurangnya komunikasi antara pengawas dan guru. Maranting (2020) menegaskan bahwa peran pengawas pendidikan agama Islam sangat signifikan dalam membantu mengarahkan guru untuk menjadi guru yang profesional, terampil dan memiliki kemampuan untuk mengembangkan keterampilan mengelola kelas.

Terkait fungsi evaluasi, Bakar (2011) melaporkan bahwa supervisi dan penilaian yang dilakukan oleh pengawas pendidikan saat ini berfokus pada masalah pelaksanaan aturan dan ketentuan serta perundangan yang telah berlaku. Dulunya, dalam melaksanakan supervisi ke lembaga pendidikan para pengawas cenderung pada mencari kekurangan atau kesalahan yang guru dalam menjalankan tugas mereka. Akan tetapi, masalah ini telah mendapat perhatian pemerintah sehingga tugas pengawas yang dulunya bersifat inspeksi atau pemeriksaan berubah menjadi pembinaan dengan tujuan agar supaya tugas menuntun dan membimbing guru yang diemban oleh pengawas dapat berjalan dengan baik dan menuai manfaat. Jika supervisor masih gagal dalam melakukan pembinaan kepada guru, maka mereka perlu melakukan evaluasi diri atas penyebab kegagalan tersebut.

Berdasarkan pemaparan terkait dengan studi yang pernah dilakukan sebelumnya di atas, dapat disimpulkan bahwa efektivitas supervisi pengawas pendidikan agama Islam adalah keberhasilan pengawas dalam melaksanakan tugas, fungsi, tanggung jawab dan wewenangnya secara efektif yang didasari oleh kompetensinya untuk mencapai tujuan pendidikan di sekolah. Implementasi dan efektivitas kinerja pengawas telah menjadi perhatian para peneliti selama beberapa dekade ini (Dunan, 2017; Herman \& Idris, 2019; Jamilus, 2019; Mette et al., 2017; Minarni, 2019; Rahabav, 2016; Soheilian, 
Inman, Klinger, Isenberg, \& Kulp, 2014). Penelitian-penelitian tersebut berfokus pada beragam aspek-aspek supervisi oleh pengawas di berbagai bidang, termasuk pengawasan bidang pendidikan agama Islam. Aspek yang menjadi perhatian termasuk pengawasan, pemantauan, kunjungan, serta penilaian pengajaran. Ada juga penelitian yang fokus mengevaluasi pelaksanaan pengawasan daripada melihat proses implementasi secara keeluruhan. Meskipun sebagian besar penelitian tersebut juga fokus pada proses pengawasan pendidikan agama Islam. Akan tetapi, penelitian yang fokus pada implementasi pemberdayaan pengawas terhadap efektivitas pengawas pendidikan agama Islam masih kurang dieksplorasi. Oleh karena itu, penelitian ini bertujuan untuk menginvestigasi apakah pengawas pendidkan agama Islam telah diberdayakan oleh pemerintah sesuai dengan tujuan yang diharapkan.

\section{Metode Penelitian}

Jenis penelitian yang digunakan adalah deskriptif kualitatif yakni usaha memberikan gambaran tentang situasi dari kejadian secara sistematis dan faktual mengenai faktor, sifat dan masalah yang akan diteliti yakni implementasi pemberdayaan pengawas terhadap efektivitas pengawas pendidikan agama Islam. Penelitian ini melibatkan pengawas pendidikan agama Islam yang tergabung di dalam Kelompok Kerja Pengawas Pendidikan Agama Islam dan guru pendidikan agama Islam di beberapa sekolah yang tersebar di Kota Kendari, Sulawesi Tenggara, Indonesia sebagai partisipan. Data diperoleh melalui observasi, wawancara dan dokumentasi (Miles, Huberman, \& Saldana, 2014). Dalam melaksanakan observasi atau pengamatan, peneliti melakukan pengamatan langsung di sekolah dan melakukan pencatatan lapangan atas hal-hal terkait yang ditemukan. Selain itu, peneliti melakukan wawancara dengan partisipan dengan melakukan komunikasi langsung dengan beberapa pengawas pendidikan agama Islam dan guru pendidikan agama Islam. Selain kepada Ketua dan Sekretaris Kelompok Kerja Pengawas Pendidikan Agama Islam Kota Kendari, wawancara juga dilakukan kepada guru-guru pendidikan agama Islam di SD, SMP, dan SMA/SMK se-Kota Kendari. Di dalam artikel ini melaporkan data wawancara dari semua jenjang pendidikan, yaitu: 1) SDN A, B, dan C; 2) SMPN A, B, dan C; dan 3) SMAN Q, dan SMKN A. Untuk triangulasi data, peneliti mencari bukti pembinaan dan penilaian pengawas terhadap guru melalui penelusuran dokumen guna memperoleh data tentang kondisi lingkungan sosial, keadaan sarana dan prasarana, keadaan guru, keadaan peserta didik maupun yang berhubungan dengan administrasi pembelajaran.

Semua data yang diperoleh dari hasil penelitian akan dianalisis secara deskriptif kualitatif, dengan menggunakan mengikuti prosedur analisis data 
(Miles, dkk., 2014). Pertama, peneliti mempersiapkan data untuk dianalisis berupa transkrip wawancara, scanning materi, mengetik data lapangan dan menyusun data tersebut ke dalam jenis-jenis yang berbeda sesuai sumber informan. Kedua, peneliti membaca keseluruhan data mengenai gagasangagasan yang terkandung dalam perkataan partisipan, bagaimana gagasan tersebut dan kesan partisipan kemudian peneliti menulis catatan khusus dan umum tentang data yang diperoleh. Ketiga, peneliti menganalisis data secara detail dengan mengkoding data yakni mengambil data tulisan yang telah dikumpulkan selama proses wawancara, mensegmentasi kalimat-kalimat ke dalam kategori yang benar-benar berasal dari partisipan.

\section{Hasil dan Pembahasan}

\subsection{Implementasi Pemberdayaan Pengawas}

Inti pemberdayaan adalah menekankan pada pemberian kekuasaan, kekuatan dan daya kepada orang lain agar orang tersebut lebih berdaya. Selain itu pemberdayaan juga menekankan proses pada menstimulasi, mendorong atau memotivasi individu agar mempunyai kemampuan atau keberdayaan (Huang, 2012). Dalam konsep ini, pemberdayaan pengawas pendidikan agama Islam juga merupakan pemberian kepercayaan, kekuasaan, dorongan, tugas dan tanggung jawab yang harus benar-benar dilaksanakan sepenuhnya oleh pengawas itu sendiri. Pihak yang berwenang untuk melakukan pemberdayaan kepada pengawas pendidikan agama Islam di Kota Kendari adalah pihak pimpinan Kantor Kementerian Agama yang implementasinya dapat diukur melalui empat indikator yaitu pemberian kepercayaan, kekuasaan, dorongan dan pelaksanaan tugas dan tanggung jawab pengawas pendidikan Agama Islam (Sufiani, 2006).

\subsubsection{Pemberian kepercayaan pada pengawas pendidikan agama Islam}

Ketua Kelompok Kerja Pengawas Pendidikan Agama Islam sebagai salah satu partisipan dalam penelitian ini menyatakan bahwa mereka selalu diberi kepercayaan dan kebebasan oleh atasan untuk bertindak dalam melaksanakan tugas sesuai dengan ketentuan yang berlaku sehingga mereka bisa lebih kreatif dan lebih percaya diri dalam bekerja. Dengan kepercayaan yang diberikan tersebut maka pengawas akan lebih termotivasi dalam meningkatkan prestasi kerjanya. Sementara itu, Sekretaris Kelompok Kerja Pengawas Pendidikan Agama Islam juga menyatakan dalam petikan wawancara berikut:

"Dengan kepercayaan yang diberikan kepada pengawas pendidikan agama Islam, maka kami berusaha membekali diri dalam meningkatkan kecakapan, pengetahuan dan keterampilan terhadap tugas profesi melalui pendidikan, 
pelatihan dan lain-lain. Dengan bekal kemampuan yang dimiliki tersebut kami dapat melaksanakan tugas dengan penuh tanggung jawab" (Wawancara, Sekretaris Kelompok Kerja Pengawas Pendidikan Agama Islam).

Sehubungan dengan hal itu, anggota Kelompok Kerja Pengawas Pendidikan Agama Islam juga mengemukakan pula bahwa pengawas yang diberi kepercayaan untuk bertindak sesuai dengan ketentuan yang berlaku akan lebih kreatif dan lebih percaya diri dalam bekerja dan lebih termotivasi dalam meningkatkan prestasi kerjanya. Hal ini mempertegas konsep pemberdayaan (Huang, 2012; Sufiani, 2006) bahwa melalui kepercayaan yang diberikan oleh pimpinan, para pengawas akan lebih termotivasi dalam meningkatkan prestasi kerjanya. Pelimpahan kepercayaan adalah salah satu cara atasan dalam memberdayakan bawahannya dalam melaksanakan tugastugas pimpinan yang sesuai dengan tingkat kewenangannnya dalam pengambilan keputusan khususnya terkait hal teknis pelaksanaan tugas.

Setiap pengawas senantiasa menginginkan untuk diberi kepercayaan oleh atasannya, khususnya hal-hal yang berkaitan dengan tugas pokok, wewenang dan tanggung jawabnya sebagai pengawas. Hal itu selaras dengan yang dikemukakan oleh Huang (2012) bahwa pemberdayaan adalah upaya memberikan otonomi dan kepercayaan dalam suatu organisasi serta mendorong mereka untuk kreatif agar dapat menyelesaikan tugasnya sebaik mungkin. Oleh karena itu, pengawas harus berusaha membekali diri guna meningkatkan kecakapan, pengetahuan, dan keterampilan terhadap tugas profesinya melalui pendidikan dan pelatihan dalam rangka pendalaman tugas pengawas. Dengan bekal kemampuan yang dimiliki pengawas tersebut, atasan tidak merasa ragu untuk memberikan kepercayaan dalam pelimpahan tugas, khususnya yang berkaitan dengan tugas-tugas teknik kepengawasan. Pengawas yang profesional juga dapat memuaskan pihak sekolah/guru yang disupervisi sehingga menjadi modal bagi pengawas untuk mempromosikan diri pada atasannya. Pengawas yang diberi kepercayaan untuk bertindak dalam melaksanakan tugas sesuai dengan ketentuan yang berlaku akan lebih kreatif dan lebih percaya diri dalam bekerja.

\subsubsection{Pemberian kekuasaan kepada pengawas pendidikan agama Islam}

Terkait pemberian kekuasaan kepada pengawas pendidikan agama Islam dalam penelitian ini, Ketua Kelompok Kerja Pengawas Pendidikan Agama Islam menyatakan bahwa "kami selalu diberi kekuasaan oleh atasan berdasarkan aturan-aturan yang ada sehingga kami mampu memberikan pembinaan terhadap guru berdasarkan pendekatan persuasif dan partisipatif" Sebagai contoh, jika hasil temuan pengawas dalam melakukan supervisi di sekolah masih berada pada tingkat kekuasaan atau kewenangan pengawas maka masalah tersebut harus diselesaikan pada tingkat pengawas. Sementara itu, Sekretaris Kelompok Kerja pengawas pendidikan agama 
Islam meyakini bahwa atasan tidak perlu turun langsung ke sekolah/madrasah. Atasan bisa terlibat kecuali diperlukan atau pengambilan keputusan atas masalah yang terjadi tidak dapat diselesaikan pada tingkat kewenangan pengawas. Dengan adanya pemberian kekuasaan atau kewenangan atasan yang dimaksud maka pengawas akan lebih berdaya dalam melakukan tugas pengawasan sehingga efektivitas kerjanya akan tercapai sesuai dengan tujuan yang diharapkan.

Setiap pengawas sangat mengharapkan adanya pemberian kekuasaan atau kewenangan dari pimpinan dalam pelaksanaan tugas-tugasnya sebagai pengawas. Hal tersebut sejalan dengan yang dikemukakan oleh Yuliani (2016) bahwa inti pemberdayaan adalah pendelegasian kekuasaan dan pengambilan keputusan dari atasan ke tingkat yang lebih rendah. Pemberian kekuasaan disini berarti bahwa pimpinan mengalihkan sebagian kekuasaan kepada pengawas sepanjang tugas-tugas tersebut masih dalam lingkup kewenangan yang dimiliki pengawas. Oleh karena itu, pengawas harus meningkatkan keahliannya baik pengetahuan maupun keterampilan melalui pendidikan dan pelatihan. Pengawas harus betul-betul bisa menggunakan kekuasaan yang dimilikinya. Pemberian kekuasaan dalam pengambilan keputusan pada hal-hal tertentu harus berpedoman pada aturan yang ada, tidak berdasarkan keinginan pengawas. Dengan kekuasaannya pengawas hendaknya mampu membina guru dengan menggunakan pendekatan partisipatif.

\subsubsection{Pemberian dorongan kepada pengawas pendidikan agama Islam}

Keberhasilan suatu organisasi sangat tergantung pada pola kepemimpinan atasan. Oleh karena itu pimpinan harus mampu membawa lembaganya ke arah tujuan yang ingin dicapai. Pimpinan bertanggung jawab atas kelancaran urusan organisasi termasuk dalam bidang kepengawasan. Salah satu diantaranya adalah memberi motivasi atau dorongan kepada pengawas untuk meningkatkan pengetahuan dan keterampilan dalam rangka peningkatan profesionalismenya. Dalam hal pemberian dorongan kepada pengawas pendidikan agama Islam, dalam wawancara dengan anggota Kelompok Kerja Pengawas Pendidikan Agama Islam salah seorang pengawas menyatakan sebagai berikut:

"kami didorong oleh pimpinan untuk mencari peluang dan kesempatan dalam upaya mengingkatkan pengetahuan dan keterampilan, karir dan prestasi. Selain daripada itu kami pula diberi dorongan untuk menggunakan kemampuan dan pengalaman yang kami miliki untuk menyelesaikan masalah yang berhubungan dengan pelaksanaan tugas." (Wawancara, Pengawas1) 
Pengawas yang ingin maju adalah mereka yang mempunyai dorongan untuk selalu meningkatkan prestasi kerjanya. Hal ini sejalan dengan argumen Yuliani (2016) bahwa pemberdayaan memiliki makna pemberian dorongan untuk selalu meningkatkan kualitas diri. Dengan demikian, pengawas harus senantiasa memotivasi diri sendiri, bekerja keras untuk meningkatkan karir, dan mencapai target-target agar lebih profesional. Selain mencapai target pribadi, penngawas juga membuat target yang ingin dicapai bersama-sama dengan guru di sekolah. Oleh karena itu, seorang pimpinan memegang peranan yang sangat penting dan wajib memberikan dorongan kepada pengawas dalam meningkatkan efektivitas pelaksanaan tugasnya misalnya dengan memberikan kesempatan yang sama kepada pengawas untuk mengikuti pendidikan kepada jenjang yang lebih tinggi, mengikuti pendidikan dan pelatihan kedinasan, memberikan fasilitas dan sebagainya.

\subsubsection{Pelaksanaan tugas dan tanggung jawab pengawas}

Dalam pelaksanaan tugas dan tanggung jawab pengawas, pimpinan harus melakukan berbagai usaha agar dapat meningkatkan tanggung jawab pengawas dalam menyelesaikan tugasnya secara efektif. Misalnya, pimpinan dapat memberikan teguran secara persuasif kepada pengawas yang melalaikan tugas, mendorong mereka untuk bekerja dengan baik, memberikan arahan kepada mereka untuk melaksanakan keputusan organisasi, dan sebagainya. Terkait hal ini, Sekretaris Kelompok Kerja Pengawas Pendidikan Agama Islam mengemukakan bahwa pimpinan mengumpulkan mereka setiap bulan untuk mengadakan rapat yang membahas tentang tugas pokok pengawas sesuai dengan jadwal yang telah disusun dalam rangka melakukan pembinaan, bimbingan dan penilaian kepada guru. Selain itu, pertemuan bulanan ini membahas berbagai kendala teknis dalam pelaksanaan supervisi sebagai bahan laporan kepada atasan.

Pelaksanaan tugas dan tanggung jawab merupakan salah satu faktor penting dalam upaya peningkatan efektivitas supervisi pengawas. Pelaksanaan tugas dan tanggung jawab ini diukur dari sejauh mana keberhasilan pengawas dalam menyelesaikan semua pekerjaan yang telah dibebankan kepadanya dengan penuh tanggung jawab, tidak meninggalkan pekerjaan sebelum selesai, dan siap menerima resiko atas keputusan organisasi (pimpinan). Hal ini mengonfirmasi argumen Yuliani (2016) yang mengemukakan bahwa pemberdayaan merupakan pemberian tugas dan tanggung jawab oleh manajer kepada pekerja dalam rangka mencapai tujuan organisasi. Oleh karena itu, seorang pimpinan harus memberdayakan pengawas sesuai dengan tugas pokok, wewenang dan tanggung jawabnya sehingga mereka dapat melaksanakannya secara efektif. 


\subsection{Efektivitas Supervisi Pengawas Pendidikan Agama Islam}

Efektivitas merupakan upaya untuk melakukan hal-hal yang tepat dalam rangka pencapaian sasaran-sasaran organisasi atau sebagai upaya melaksanakan semua tugas, ketepatan waktu dalam pelaksanaan serta tercapainya tujuan. Pengawas pendidikan agama Islam telah melakukan berbagai usaha dalam menjalankan tugas pokok, wewenang dan tanggung jawabnya dalam pembinaan dan penilaian terhadap guru pendidikan agama Islam di Kota Kendari berdasarkan tiga indikator, yaitu pembinaan guru dalam hubungan struktural, pembinaan dan penilaian administrasi guru, serta pembinaan dan penilaian akademik guru.

\subsubsection{Pembinaan guru dalam hubungan struktural}

Terkait pembinaan guru dalam hubungan struktural, berikut adalah hasil wawancara dengan guru pendidikan agama Islam di salah satu SDN A di Kota Kendari. Ia menyatakan bahwa pengawas melakukan beberapa kegiatan yakni pembinaan guru dalam hubungan struktural, pembinaan dan penilaian administrasi guru, serta pembinaan dan penilaian akademik guru. Hal ini senada dengan yang diungkapkan oleh guru pendidikan agama Islam di SMPN A di Kota Kendari yang mengungkapkan bahwa "pengawas menerangkan terlebih dahulu maksud kedatangannya pada kepala sekolah sebelum melakukan supervisi dan dalam melakukan supervisi pengawas tidak beranggapan bahwa kepala sekolah dan guru sebagai bawahannya sehingga kami dapat saling belajar". Hal ini diperkuat dengan pengakuan salah seorang guru pendidikan agama Islam di SMAN A di Kota Kendari bahwa jika dalam pelaksanaan supervisi terjadi perbedaan pendapat dengan guru mata pelajaran maka pengawas mencari kesepakatan sesuai dengan peraturan atau ketentuan yang berlaku.

Hasil penelitian ini mengungkap bahwa hubungan struktural yang dimaksud oleh para guru pendidikan agama Islam adalah hubungan rekan kerja antara pengawas dan guru, dan bukan posisi pengawas sebagai seseorang yang lebih tahu daripada guru. Dengan demikian, apabila terjadi perbedaan pendapat antara pengawas dan guru maka pengawas tidak mempertahankan pendapatnya. Hal tersebut mengonfirmasi kompetensi pengawas yaitu kompetensi sosial sehingga mampu bekerja sama dengan berbagai pihak dalam rangka meningkatkan kualitas diri untuk melaksanakan tugas dan tanggung jawabnya (Dunan, 2017). Rohman (2018) juga menegaskan bahwa pengawas sekolah yang memiliki kompetensi sosial akan selalu berupaya melakukan perencanaan pengawasan untuk kepentingan peningkatan mutu pendidikan dan pengawas sekolah yang akan tercermin dari sikapnya dalam membina hubungan kerja dengan berbagai guru maupun kepala sekolah. 


\subsubsection{Pembinaan dan penilaian administrasi guru}

Berkenaan dengan pembinaan dan penilaian administrasi guru yang dilakukan oleh pengawas pendidikan agama Islam, salah seorang guru pendidikan agama Islam di SDN B di Kota Kendari menyatakan bahwa pengawas pendidikan agama Islam melaksanakan supervisi administrasi pembelajaran berupa kalender pendidikan, program tahunan, program semester, silabus, RPP dan bahan ajar serta administrasi penilaian. Pengakuan tersebut diperkuat oleh guru pendidikan agama Islam lain yang menyatakan bahwa apabila ada guru yang belum lengkap administrasi pembelajarannya, maka pengawas menyarankan untuk melengkapinya serta memberi penilaian sesuai dengan prosedur yang berlaku. Sementara itu, salah seorang guru pendidikan agama Islam di SMPN B di Kota Kendari menyatakan bahwa pengawas mengarahkan guru yang belum mampu menguasai penyusunan administrasi pembelajaran dan apabila terjadi perbedaan pendapat dengan guru mata pelajaran, maka pengawas mencari kesepakatan sesuai dengan peraturan yang berlaku. Selain itu, salah seorang guru di SMKN A di Kota Kendari menambahkan bahwa dalam kegiatan supervisi pengawas menanyakan beberapa hal yang berkaitan dengan administrasi pembelajaran yang dilakukan beberapa kali dalam satu semester.

Hasil penelitian ini membuktikan bahwa teknik yang digunakan oleh pengawas dalam pembinaan administrasi guru secara umum adalah teknik individu dan teknik kelompok. Penggunaan teknik individu lebih bersifat informal, kekeluargaan dan lebih bersifat insidental. Pertemuan individual yang dilakukan oleh pengawas dalam membina guru berkaitan dengan tugastugas untuk melengkapi administrasi guru dilakukan dengan jalan mengidentifikasi secara teliti kelemahan masing-masing guru dalam melengkapi administrasi yang disyaratkan. Kenyataannya, masih ditemukan guru yang lemah dalam memahami secara baik rencana persiapan pembelajaran atau RPP, sementara ada juga guru yang lemah dalam hal menyiapkan dan melaksanakan evaluasi. Sedangkan penggunaan teknik kelompok lebih bersifat formal dan melibatkan beberapa orang guru pendidikan agama Islam sekaligus. Penggunaan kedua teknik ini telah membuahkan hasil yang mengembirakan dalam pembinaan administrasi guru (Slameto, 2016).

\subsubsection{Pembinaan dan penilaian akademik guru}

Dalam hal pembinaan dan penilaian akademik guru oleh pengawas, hasil wawancara dengan guru pendidikan agama Islam di SDN C di Kota Kendari mengungkap bahwa pengawas memberikan arahan atau saran kepada guru 
dalam rangka meningkatkan kemampuan profesionalnya dalam aspek akademik karena guru sebagai agen pembelajaran dan ujung tombak keberhasilan pendidikan. Guru pendidikan agama Islam di SMP Negeri C di Kota Kendari mengakui bahwa dalam kegiatan supervisi kunjungan kelas, pengawas melakukan penilaian terhadap guru mulai dari kegiatan pendahuluan, kegiatan inti dan kegiatan penutup dalam proses pelaksanaan pembelajaran. Pengawas juga memberikan beberapa solusi yang tepat dalam pemilihan model dan metode pembelajaran yang sesuai dengan karakteristik peserta didik dan karakteristik mata pelajaran. Sementara itu, guru pendidikan agama Islam di SMA Negeri B di Kota Kendari mengungkap bahwa pengawas memberikan pembinaan terhadap guru atas dasar rasa tanggung jawab dengan mengedepankan pendekatan profesional. Pengawas pula membantu guru dalam menyusun desain pembelajaran untuk membina guru dalam menghubungkan antara model, metode, media dengan materi pembelajaran.

Hasil penelitian ini mengungkap bahwa pengawas pendidikan agama Islam di kota Kendari telah melaksanakan supervisi secara efektif yang berhubungan dengan tugas, wewenang dan tanggung jawabnya. Pengawas dituntut untuk melakukan pembinaan terhadap guru agar sesuai dengan tuntutan mutu pendidikan (Jamilus, 2019). Pembinaan untuk mengembangkan kemampuan profesional guru dalam bekerja merupakan sebuah hal yang sangat diperlukan agar mereka berkembang ke arah yang lebih baik sesuai perubahan yan diinginkan. Kinerja guru merupakan hasil kerja yang dicapai di suatu lembaga pendidikan sesuai dengan tugas dan tanggung jawabnya dalam mencapai tujuan pendidikan. Dalam mencapai kinerja yang maksimal perlu didukung dengan kompetensi yang harus dimiliki seorang guru untuk menjalankan tugasnya yang diperkuat oleh pembinaan dan penilaian pengawas.

\section{Kesimpulan}

Berdasarkan hasil penelitian, dapat disimpulkan bahwa pejabat yang berwenang telah memberdayakan pengawas pendidikan agama Islam melalui pemberian kepercayaan, kekuasaan, dorongan dan pelaksanaan tugas dan tanggung jawab. Pengawas pendidikan agama Islam telah melaksanakan tugas, wewenang dan tanggung jawabnya melalui pembinaan guru dalam hubungan struktural, pembinaan dan penilaian administrasi guru serta pembinaan dan penilaian akademik guru.

\section{Daftar Pustaka}

Adu, E. O., Akinloye, G. M., \& Olaoye, O. F. (2014). Internal and external school supervision: Issues, challenges and wayforward. International 
Journal of Educational Sciences, 7(2), 269-278. https://doi.org/10.1080/09751122.2014.11890189

Alimin, Taena, L., \& Suardika, I. K. (2018). Analisis kompetensi profesionalisme pengawas SMP di Kabupaten Konawe Selatan. Jurnal Wahana Kajian Pendidikan IPS, 2(2), 318-325.

Amiruddin. (2018). Urgensi pengembangan supervisi elektronik berbasis website bagi pengawas pendidikan agama Islam di lingkungan Kementerian Agama Kabupaten Sumenep. Kariman, 6(1), 171-181.

Bakar, A. (2011). Supervisi pendidikan agama Islam. Jurnal Sosial Budaya, $8(1), 1-24$.

Dunan, H. (2017). Upaya Kasi Pendidikan Agama dan Keagamaan Islam dalam pembinaan kinerja pengawas PAI. Al-Bahtsu, 2(1), 61-72.

Gusmadi. (2014). Pelaksanaan manajemen pengawasan pendidikan agama Islam di SMA negeri di Kabupaten Tanah Datar. Al-Fikrah: Jurnal Manajemen Pendidikan, 2(2), 133-142. https://doi.org/10.31958/jaf.v2i2.378

Hendri, N. (2020). Efektivitas supervisi akademik pengawas PAI dalam membina guru agama SMP dan SMA di Kecamatan Ipuh Kabupaten Mukomuko. Pedagogi: Jurnal Ilmu Pendidikan, 20(2), 111-118.

Herman, \& Idris, J. (2019). Implementasi model supervisi berbasis keikhlasan dalam peningkatan kinerja guru PAI di SMP negeri Kabupaten Nagan Raya. Jurnal At-Tafkir, 12(2), 168-184.

Huang, J. T. (2012). Be proactive as empowered? The role of trust in one's supervisor in psychological empowerment, feedback seeking, and job performance. Journal of Applied Social Psychology, 42(S1), 103-127. https://doi.org/10.1111/j.1559-1816.2012.01019.x

Jamilus. (2019). Model pelatihan berbasis need assesment dalam meningkatkan kompetensi supervisi akademik pengawas PAI. AlFikrah: Jurnal Manajemen Pendidikan, 7(2), 139-154. https://doi.org/10.31958/jaf.v7i2.1639

Maranting, H. (2020). Peranan pengawas pendidikan agama Islam dalam meningkatkan kualitas guru (Studi kasus di MTs Al-Khairaat Kota Gorontalo). Tadbir: Jurnal Manajemen Pendidikan Islam, 8(1), 76-87.

Mette, I. M., Range, B. G., Anderson, J., Hvidston, D. J., Nieuwenhuizen, L., \& Doty, J. (2017). The wicked problem of the intersection between supervision and evaluation. International Electronic Journal of Elementary Education, 9(3), 709-724.

Miles, M. B., Huberman, A. M., \& Saldana, J. (2014). Qualitative data analysis (3rd ed.). SAGE.

Minarni, M. (2019). Supervisi akademik pengawas guru PAI pada madrasah di Kota Bengkulu. Al-Bahtsu, 4(1), 134-142.

Nasution, E. (2014). Problematika pendidikan di Indonesia. Mediasi, 8(1), 1- 
10.

Oma, W. (2012). Efektivitas supervisi pengawas sekolah (Hubungan korelasional antara pemberdayaan pengawas dan komunikasi organisasi dengan efektivitas supervisi pengawas sekolah di Kabupaten Muna). Tesis tidak dipublikasikan. Universitas Muhammadiyah Jakarta.

Pristiwaluyo, T., \& Hakim, F. A. (2018). Pengaruh kompetensi kepribadian dan kompetensi sosial terhadap pelaksanaan supervisi akademik pengawas sekolah menengah atas. Jurnal Administrare: Jurnal Pemikiran Ilmiah dan Pendidikan Administrasi Perkantoran, 5(2), 6372. https://doi.org/10.26858/ja.v5i2.7883

Rahabav, P. (2016). The effectiveness of academic supervision for teachers. Journal of Education and Practice, 7(9), 47-55.

Rahmah, S. (2018). Pengawas sekolah penentu kualitas pendidikan. Jurnal Tarbiyah, 25(2), 174-193. https://doi.org/10.30829/tar.v25i2.378

Rohman, M. A. A. (2018). Kompetensi pengawas PAI dan efektivitas kepemimpinan kepala madrasah dalam mengembangkan profesionalisme guru madrasah tsanawiyah di Kabupaten Ponorogo. Qalamuna, 10(2), 69-88.

Slameto. (2016). Supervisi pendidikan oleh pengawas sekolah. Kelola: Jurnal Manajemen Pendidikan, 3(2), 192-206. https://doi.org/10.24246/j.jk.2016.v3.i2.p192-206

Soheilian, S. S., Inman, A. G., Klinger, R. S., Isenberg, D. S., \& Kulp, L. E. (2014). Multicultural supervision: supervisees' reflections on culturally competent supervision. Counselling Psychology Quarterly, 27(4), 379392. https://doi.org/10.1080/09515070.2014.961408

Sufiani. (2006). Hubungan pemberdayaan pengawas dengan efektivitas supervisi pengawas sekolah di lingkungan Kantor Departemen Agama Kabupaten Muna. Tesis tidak dipublikasikan. Universitas Islam Negeri Alauddin Makassar.

Widodo, H. (2015). Potret pendidikan di Indonesia dan kesiapannya dalam menghadapi Masyarakat Ekonomi Asia (MEA). Cendekia: Journal of Education and Society, 13(2), 293-307. https://doi.org/10.21154/cendekia.v13i2.250

Yuliani, F. (2016). Kebijakan restrukturisasi organisasi dan pemberdayaan sumber daya manusia. Jurnal Administrasi Pembangunan, 4(2), 87156. 